\title{
Strengthening Student Competency in Making Social Science Learning Media, Social Science Development Courses
}

Tutuk Ningsih $^{(1)^{*}}$, Gautam Kumar Jha ${ }^{(2)}$

(1) Institut Agama Islam Negeri Purwokerto, Indonesia

(2) Jawahalrar Nehru University, India

*Correspondence to: tutuk@iainpurwokerto.ac.id

\begin{abstract}
The teaching and learning process is not only limited to providing material, but also utilizing media that is suitable with the material to be taught. Learning media has a very important role, therefore the media in learning has a function as a tool in the teaching and learning process to engage students to be active in learning. Social science learning process requires learning media to be used by teachers to stimulate students' minds. This study aims to describe and analyze the strengthening of student competencies in making social studies learning media in Social Development courses in the Postgraduate Study Program at IAIN Purwokerto. This type of research is a qualitative study. Data collection techniques used are through observation, interviews and documentation. Development of student competency in Madrasah Ibtidaiyah Teacher Education Study Program IAIN Purwokerto develops learning media especially social science subjects at the Madrasah Ibtidaiyah education level. The results of competency development is learning media that can be used by teachers in delivering material in social science subjects. The development of media produced by students is in the form of Mini Zoo media, ASEAN Box media and Traditional and Modern Markets Miniature media.
\end{abstract}

Keywords: strenghtening; student competency; learning; media; social science

Recommended citation: Ningsih, T., \& Jha, G. K. (2021). Strengthening Student Competency in Making Social Science Learning Media, Social Science Development Courses. Journal of Innovation in Educational and Cultural Research, 2(1). 1-6.

\section{INTRODUCTION}

Teaching and learning process can be successful if there is a supportive learning component. Thus, teachers and students will interact educatively, learning becomes more effective, and learning objectives can be achieved. Therefore, the teaching and learning process is not only limited to providing material, but also utilizing media that is matched with the material to be taught. Learning media has an important role in learning process, therefore it has functions as a tool in engaging students to be active in learning the learning process.

Arsyad (2004) stated that the use of instructional media in the teaching and learning process can arouse desire and interest, motivation, and bring psychological influences to students. The use of media in the learning process greatly helps students in achieving learning goals. Learning media used by teachers in the teaching and learning process has a function as a medium for communicating in learning. It is in line with Arief, cited in Sadiman (2009) who said that teaching and learning process is essentially a communication process, namely the process of delivering messages from the source of messages through channels or certain media to the recipient of the message. Message sources, channels or media and message recipients are the components of the communication process. The communication component in the learning process serves to support students learning effectively and efficiently. In the learning process, such as social science learning requires media that is suitable with the material taught by the teacher. Social science studies people's lives and problems of social life. Therefore, instructional media is needed to construct the child's mind. Thus, students will enjoy social science subject.

However, there is phenomenon that occurs in the learning process, teachers still do not use learning media, so that the material presented by the teacher cannot be well received by students. This is consistent with the opinion delivered by Sanjaya (2012) who stated that social studies learning in schools is presented in factual form. The teacher only pursues the target of finishing the curriculum, not concerned with the process. Therefore, social science learning has the impression of being saturating and boring. Thus, students often consider social science as less enjoyable. 
Suarno and Sukirno (2015) suggested that the themes taught in social science learning are mostly theoretical. It becomes the reason why students need a long time to understand these materials. The difficulty of students in understanding the material can be helped by media visualization. The material is composed of themes developed in various aspects such as geography, history, economics, and sociology. Thematic learning in its explanation is not supposed to be delivered verbally. As meant by the theory, the social science lesson requires media that is appropriate with the material. A teacher must be creative in delivering learning material, bringing students to make social science lessons in fun way. This is the challenge for the teacher in teaching social studies to be more fun. Therefore, social science learning requires media that is appropriate to the material and characteristics of the students.

From the above phenomenon, it is necessary to have an innovation made by the teacher to design media in social science learning. In this regard, it is the duty of prospective educators or teachers to be able to create conditions for student learning to be more active. Therefore we need the development of competencies and skills for prospective educators in creating learning innovations. Innovations in developing learning media can be done by Teacher Educaton of Madrasah Ibtidaiyah (PGMI) students. As a student, developing competencies and skills is a must-have component. In the world of higher education, competencies can be developed through various approaches. One of them is the learning process in the classroom that allows everyone to be ready to face the trends of globalization and technological developments (both information and others) that are changing rapidly. Opportunities for students are during the education process to hone the competence of young generation.

Competencies owned by students and developed in lectures will become an experience in the learning process, as stated by the research results by Kanah, et al. (2019) Competency standards are not only the ability to complete tasks but also based on how and why the task is done. In other words, competency standards include supporting factors such as knowledge and ability to carry out a task under normal conditions in the workplace as well as the ability to transfer and apply skills and knowledge in different situations and environments. It is a formulation on the expertise that a person must own to carry out a task/work based on knowledge, skills and work attitudes, following the required performance criteria. Therefore, the development of student competencies in creating social studies learning media will significantly hone the student's outlook so that the media produced by students will be useful for teachers of both Islamic and non-Islamic elementary schools.

The purpose of this research is to describe and analyze the strengthening of student competencies in creating social studies learning media for the social science development course in IAIN Purwokerto PGMI Masters programs. The theoretical benefit of the research is to strengthen student competencies in creating social studies learning media in Social Science Development course. Meanwhile, the practical benefits of this study are as a reference and fundamental foundation for tertiary institutions in developing scientific repertoire in the field of primary education.

The word media comes from the Latin language and is a plural form of the word medium which literally means an intermediary or introduction. The media is an intermediary or introduction to the message from the sender to the recipient of the message (Sadiman, 2009). Media in the teaching and learning process tends to be interpreted as graphic, photographic, or electronic tools for capturing, processing, and rearranging visual or verbal information. If the media carries messages or information that has instructional purposes or contains teaching purposes, then the media is called learning media (Arsyad, 2004).

In making learning media, a teacher must also pay attention to the feasibility of costs, why do we have to choose the expensive if it is equally effective. From some of the criteria or steps for media selection which has been mentioned by the experts above, it can be concluded that several considerations need to be made by the teacher to choose the media, namely; a. Consideration of students, b. Consideration of learning objectives, c. Consideration of learning strategies, d. Consideration of ability to design and use media, e. Cost considerations, f. Consideration of facilities and infrastructure, and h. Consideration of efficiency and effectiveness (Mahnun, 2012).

Learning media has a very important position in the learning process. Learning media aims to make the learning process run effectively and efficiently. Media or learning resources consist of various types. There are media or printed learning resources, electronic learning media or sources and media or sources that come from the social environment where the students are. In order to make the media or source can really be used properly, it requires skills in obtaining, reading and using it, including: Social science textbooks which consist of textbooks published in primary schools are the main media or sources that are always used by social science teachers in elementary schools (SD) or Madrasah Ibtidaiyah (MI) to develop the learning process in class. With this social science textbook, students are expected to be able to think more critically, and be able to analyze as well as develop knowledge in the social studies textbooks that they learn. Through the reading 
process, each student is expected to later be able to construct knowledge and students can be more practical in the ongoing learning process in class. Some print media that are usually used by teachers as a supporting tool in the process of social science learning in SD / MI student are books, magazines, newspapers, charts, maps and graphics.

Electronic media is very effectively used in the social science learning process. However, in principle, electronic media has the potential to alienate students from the intrinsic aspects of their lives as social beings. Obviously social beings are creatures that can interact with their kind directly, but with the presence of electronic media, it can be a barrier in social interaction. One effort that can be done by teachers to overcome these problems is by trying to balance the use of electronic media that is instant with other concrete social media, so that students can develop aspects of Emotional Quotient (EQ) with benefits that will be useful for students in socializing in the community environment. Electronic devices are one of the media or learning resources that can be used to support social science learning processes in SD / MI, namely, computers, LCD, radio, television, and other electronic media.

Social science as an effective scientific discipline and focus on the study of humans in the community has an important role in the current global situation. In social science learning, teachers must be able to produce concepts that are relevant between the social sciences and also need to include elements of education and social problems in community life, but in reality, teaching social science is dominated by teaching and learning processes using textbook. There are four types of environments that can be used as a source of material for social knowledge, among others, the social environment, the natural environment, the religious environment, and the human environment as a resource (Rachmah, 2014).

Social science is a compulsory subject and it is clearly revealed since the 1975 curriculum. In the broad life curriculum, social science encompasses the disciplines of Geography, History and Economics as the main disciplines. For SD / MI education units, social science subjects use an approach in accordance with the ideas of social science, while for Madrasah Tsanawiyah (MTs) or junior high school (SMP) education units use a separate approach. For the social science curriculum, at the secondary education level, social science material includes Geography and population, History, Cultural Anthropology, Economics and Cooperatives, as well as Bookkeeping and Trade Count (Gunawan, 2013)

Social science is one of the subjects that is given from SD / MI / SDLB to SMP / MTs / SMPLB. Social sciences examine a set of events, facts, concepts and generalizations related to social issues. At the level of SMP or MTs, social science subjects contain material Geography, History, Sociology, and Economics. Through Social science subjects, students are directed to become democratic and peaceful citizen of the world (Murni, 2017). So that social sciences can simply be interpreted as a combination of various parts of the concepts that are mixed for the benefit of education and learning programs in schools / madrasah.

In essence, standard competency are a way to get good and professional teachers who have the competence to carry out the functions and objectives of schools in particular, as well as educational goals in general, in accordance with community needs and demands (Mulyasa, 2013). Teacher competence is a combination of personal, scientific, technological, social, and spiritual abilities that formally constitutes the standard competency of the teacher's profession, which includes mastery of the material, understanding of students, learning that educates, personal development, and professionalism. In the Law of the Republic of Indonesia No. 14 of 2005 concerning teachers and lecturers, it is explained that competency is a set of knowledge, skills and behaviors that must be possessed, internalized, and mastered by the teacher or lecturer in carrying out professional duties. In the world of higher education, competencies can be developed through a variety of approaches, one of which is the learning process in the classroom that enables everyone to be ready to face the trends in globalization, technological developments (both information and others) that are changing rapidly. Opportunities for students are during the process of education will be able to hone the high competence of young people (Tantri \& Ananda, 2018).

\section{METHODS}

The approach used in this research is a qualitative descriptive approach. A qualitative approach is used and implemented by a group of researchers in the social sciences, including education. Data collection techniques in this study used observation and documentation techniques. The analysis in this study uses a descriptive analytic method, which describes the data collected in the form of student competencies in making media for social science learning. The object in this study is the strengthening of student competencies in creating social studies learning media. The research subject, or respondents chosen as the first subject, were second-semester students of PGMI Masters program. 


\section{RESULTS AND DISCUSSION}

Creating a social science learning media that will be used by social science teachers is not easy. It takes thought and hard work in order to produce good learning media used for the learning process. Therefore, it needs innovation and creativity in creating a learning media. One aspect that plays an important role in creating a learning media is students. The development of student competencies can be carried out by students, especially students of the Madrasah Ibtidaiyah Study Program IAIN Purwokerto, one of which is in the Social Science Development course. This becomes an appropriate chance to accommodate students' competency as prospective educators. Therefore, students of the Madrasah Ibtidaiyah Study Program of IAIN Purwokerto will develop products in the form of learning media for Social Sciences subjects.

The results of this development are in the form of social science learning media products that are adapted to the material in first grade through sixth grade of Madrasah Ibtidaiyah. The product of this media will be applied both in schools and in teaching practices during lectures, in addition to that it can be used in schools in a broad scope. The media produced by these development products are socialized both through teacher scientific forums and through online by socializing in social media. This is so that the learning media products can become references used by teachers in the education process. The material for social studies is vast and extensive, so it requires concrete and useful media, so students remain interested in social studies. As concluded by the research of Mulyadi, et al. (2018), learning through audio-visual media can improve students' ability to understand the material and change student learning behaviour. Students become more active in asking better questions, be more interested, and the learning process becomes fun. For example, in teaching the social studies subject of Business and Economic Activities in Indonesia, students understand the materials more readily, are active, and bad behaviour (such as drowsiness in class, looking for attention and acting rowdy) can be reduced in the learning process.

The making of learning media for social science subjects is made by students through the following steps: Students look for social science material at the MI level from first grade to sixth grade, both thematic and non-thematic based material; Students find material and adapt it to the media to be made and then design what media is suitable for the material; Students explain the media prototype with unfinished images and the steps for making it. Moreover they also describe how to use the media in class discussion; Students revise the media design based on input from the results of the discussion in class; Completed media that are ready to be put into practice are then used in microteaching practised in undergraduate student forums.

Furthermore, students uploaded learning media videos in online media, such as YouTube and the IAIN Purwokerto Postgraduate website. The learning process by using the developed learning media become one of the assessments of the learning media products created by students. During the observation period in the Social Studies Development course, the atmosphere in the media creation was extremely serious. Each student was busy with their respective media. From several observations, there were three students whose media are excellent and unique. Therefore, the students-Arif, Sudendi and Isna-were selected as the research subjects. The three students were very enthusiastic in media creation as the products will be uploaded on social media and the postgraduate web. The learning media created are as follows:

\section{3 in 1 Mini Zoo Media}

This media is created by the second semester PGMI Masters students, Arif. As explained by Arif:

"Originating from the concerns about the lack of used materials utilisation at school, I tried to do the task of creating social studies learning media based on the usage of used goods. The secondhand items I found at the school where I taught were mostly used boxes for student books and paper. In addition, I also found various types of unused materials in the school warehouse. Therefore, I created the 3 In 1 Mini Zoo media."

The 3 In 1 Mini Zoo media is unique, functional and really interesting as a social study learning media. The media is inexpensive because it is made from used materials. Therefore, the media is very suitable for use by Madrasah Ibtidaiyah teachers. After media creation is done, students demonstrate its use in class. This media is applied in the fifth-grade class material; the Spread of Flora \& Fauna in Indonesia. In teaching practice, students implemented a modification of discovery-inquiry learning strategies, discussions, and presentations. The student also applied the following learning scenarios: $a$. The teacher explains the material of flora \& fauna distribution in Indonesia, b. The teacher brings the media covered with a cloth so that students' curiosity is aroused. Arif's learning felt very similar to a fifth-grade class. The 3 In 1 Mini Zoo media made by Arif is very helpful for fifth-grade social studies teachers in selecting inspirational media. 


\section{Traditional Market and Modern Market Miniature}

Traditional Market and Modern Market Miniature Media are simple miniatures made from materials that are easy to get, affordable and inexpensive materials. This media is created to make it easier for students to understand the material being studied and make it easier for teachers to deliver the material.

In the use of Miniature Traditional Market and Modern Market learning media, there are a number of things that need attention. First, class conditions should be maintained so that the atmosphere remains calm. Second, in the learning process the teacher must write a detailed explanation on the board or transparency. Third, make sure students are not obstructed by the standing position of the teacher. Fourth, each student is monitored in using media.

Thus, the teacher can help students if they have difficulties. In addition, it can maintain class order (between groups so as not to interfere with each other). During the media presentation, it can be interspersed with questions, asking students to do something, for example pointing pictures, working on problems, or formulating something. So the learning process using these media can make students more interested, focused, and not playing alone so that learning objectives can be achieved.

\section{Exploding Box Media}

The Exploding Box media is valuable, unique and creative. It looks simple but is very complex and full of ideas and innovations in media creation. Isna, the creator, stated that:

'The formulation of the Exploding Box media is inspired by surprise boxes that are usually given to friends, relatives or others, where when the box is opened it will reveal numerous photos or even contain lots of written statements stored on various sides of the box. The media creation process is not easy because there are several stages. The making of Exploding Box involves a complicated process: it is not only about sticking different materials, but it needs high concentration so that the media can be successfully organized. However, the materials are inexpensive and affordable so that Madrasah Ibtidaiyah/elementary school teachers can easily produce this media.'

From these ideas, Isna finally made a media for the sixth-grade class with a topic on Southeast Asia regions that are part of ASEAN. The creation of the Exploding Box media facilitates teachers to teach about ASEAN so that learning objectives will be achieved. In addition to media creation, the student also made learning steps and learning strategies so that in the use of Exploding Box media, both teachers and students do not face any difficulty.

Mini Zoo media, ASEAN box media and Traditional Market and Modern Market Miniature media are products produced by students in the subject of developing social science learning. This product has gone through trial stages, both discussed in class, in front of Postgraduate PGMI students, and also lecturers supporting the Social Science Learning Development course. The media is also applied by undergraduate PGMI students so that the media produced by students is a media that is suitable for use in the teaching and learning process in Madrasah Ibtidaiyah or elementary schools.

\section{CONCLUSION}

It can be concluded based on the research and discussion on competency development of Masters students in the Madrasah Ibtidaiyah Teacher Education Study Program - which focuses on developing learning media, primarily for social studies subjects at the elementary school/Madrasah Ibtidaiyah level-that the development of student competencies in making instructional media generated learning media products that are creative, innovative, affordable and cost-effective. The media has been demonstrated in the class of fellow Masters and Undergraduate students. After being evaluated and corrected, videos of media usage were uploaded on YouTube and the IAIN Purwokerto Postgraduate website. The media were then assessed by lecturers in charge of the Social Studies Learning Development course. There are three valuable, unique and creative learning media discussed as follows: 1 . The 3 In 1 Mini Zoo media, which is unique, excellent and creative. It is a social study learning media for grade 5 covering the material of the Spread of Flora \& Fauna in Indonesia. This media is suitable for elementary school/Madrasah Ibtidaiyah teachers in social studies learning. The 3 In 1 Mini Zoo media is made from used materials and is cost-effective so that the elementary school/Madrasah Ibtidaiyah teacher will readily make the media; 2 . Traditional and Modern Markets Miniature Media. The media is great, unique and creative. This media is created for class IV, particularly used on the topic of differences between traditional markets and modern markets. This media is designed to make it easier for students to understand the material being studied and make it easier for teachers to deliver the 
material. The creation of this media is inexpensive so that it is still affordable for the teachers; 3 . Exploding Box media is valuable, unique and creative. This media is created for class VI semester I students, particularly used on the topic of ASEAN countries. There are ten countries which are part of ASEAN, and this media is made to facilitate social studies learning, especially in introducing the profile of each country to students. The making of this media is not expensive, but it is full of creative ideas.

\section{REFERENCES}

Arief, R. (1986). Media Pendidikan Pengertian, Pengembangan, dan Pemanfaatannya. Jakarta: Raja Grafindo Persada.

Arsyad, A. (2004). Media Pembelajaran. Jakarta: Raja Grafindo Persada

Gunawan, R. (2011). Pendidikan IPS, Filosofi, Konsep, dan Aplikatif. Bandung: Alfabeta.

Kanah, K., Sumawidari, I. A. K., \& Oka, I. M. D. (2019). Analisis Kompetensi Mahasiswa Program Studi Perhotelan. Epigram, 16(1).

Mulyasa, E. (2013). Standar Kompetensi dan Sertifikasi Guru. Bandung: Remaja Rosdakarya

Mahnun, N. (2012). Media pembelajaran (kajian terhadap langkah-langkah pemilihan media dan implementasinya dalam pembelajaran). An-Nida', 37(1), 27-34.

Mulyadi, M., Fahreza, F., \& Julianda, R. (2018). Penggunaan Media Audio Visual untuk Meningkatkan Prestasi Belajar pada Pembelajaran IPS Siswa Kelas V SDN Langung. Visipena Journal, 9(1).

Murni. (2017). Metodologi Pembelajaran IPS: Pengembangan Standar Proses Pembelajaran IPS di Sekolah/Madrasah. Yogyakarta: Ar-Ruzz Media.

Rachmah, H. (2014). Pengembangan Profesi Pendidikan IPS. Bandung: Alfabeta.

Sadiman, A. S. (2009). Media Pendidikan. Jakarta: Raja Grafindo Persada.

Sanjaya, W. (2012). Media Komunikasi Pembelajaran. Jakarta: Kencana Prenada Media Group.

Suarno, D. T., \& Sukirno, S. (2015). Pengembangan Media Pembelajaran IPS Dengan Tema Pemanfaatan dan Pelestarian Sungai Untuk Siswa Kelas VII SMP. Harmoni Sosial: Jurnal Pendidikan IPS, 2(2), 115-125.

Tanti, D. S. \& Ananda, I A. (2018). Analisis Kompetensi Mahasiswa dalam Menghadapi Masyarakat Ekonomi ASEAN. Jurnal Visi Komunikasi. 1(1), 1-5. 